\title{
Penerapan Model Learning Cycle Tipe 5E dengan Media Visual Untuk Meningkatkan Hasil Belajar Fisika Pada Siswa Kelas $\mathrm{X}_{\mathrm{c}}$ SMA Negeri 2 Dolo
}

\author{
Zeny Wahyuni*, Syamsu* dan Muslimin \\ *zeny.wahyuni@gmail.co.id \\ *syamsultan@yahoo.com \\ Prodi Pendidikan Fisika FKIP Universitas Tadulako \\ Jl. Soekarno Hatta KM. 9
}

\begin{abstract}
Abstrak - Penelitian ini merupakan penelitian tindakan kelas yang bertujuan untuk meningkatkan hasil belajar fisika pada siswa kelas Xc SMA Negeri 2 Dolo dengan menerapkan model learning cycle tipe $5 E$ dengan media visual, dimana learning cycle adalah model pembelajaran yang berpusat pada siswa dengan tahap-tahap yang diorganisasi sedemikian rupa sehingga membuat siswa berperan aktif dalam pembelajaran. Desain penelitian ini mengikuti model Kemmis dan Mc. Taggart dengan subyek melibatkan 21 orang siswa. Penelitian ini dilaksanakan dalam dua siklus dengan materi pokok dinamika partikel, masing-masing siklus meliputi 4 tahap: (i) perencanaan (ii) pelaksanaan tindakan (iii) observasi dan (iv) refleksi. Penerapan model learning cycle tipe 5E dengan media visual dapat meningkatkan hasil belajar fisika siswa kelas Xc. Hal ini dapat dilihat pada peningkatan hasil belajar siswa, untuk ketuntasan klasikal pada siklus I sebesar 79,16\% dan pada siklus II sebesar $90,47 \%$ dan meningkat sebesar $11,31 \%$. Untuk daya serap klasikal pada siklus I sebesar $71,19 \%$ dan pada siklus II sebesar $81,19 \%$ dan meningkat sebesar $10,00 \%$. Sedangkan untuk aktivitas guru pada siklus I diperoleh rata-rata persentase sebesar $86,25 \%$ berada pada kategori baik dan pada siklus II diperoleh rata-rata persentase sebesar $96,25 \%$ berada pada kategori sangat baik dan meningkat sebesar $10,00 \%$. Untuk aktivitas siswa pada siklus I diperoleh rata-rata persentase sebesar $77,50 \%$ berada pada kategori cukup dan pada siklus II diperoleh rata-rata persentase sebesar $95,00 \%$ berada pada kategori sangat baik dan meningkat sebesar 17,50\%.
\end{abstract}

Kata Kunci: Model Learning Cycle Tipe 5E, Media Visual, Hasil Belajar Fisika.

\section{PENDAHULUAN}

Pelaksanaan pembelajaran di dalam kelas merupakan salah satu tugas utama guru dan pembelajaran dapat diartikan sebagai kegiatan yang ditujukan pada siswa. Dalam proses pembelajaran masih sering ditemui adanya kecenderungan meminimalkan keterlibatan siswa. Dominasi guru dalam proses pembelajaran menyebabkan kecenderungan siswa lebih bersifat pasif sehingga mereka lebih banyak menunggu sajian guru dari pada mencari dan menemukan sendiri pengetahuan, keterampilan atau sikap yang mereka butuhkan.

Berdasarkan hasil observasi awal yang dilakukan di SMA Negeri 2 Dolo, kondisi pembelajaran fisika masih belum memuaskan. Siswa menganggap pelajaran fisika adalah pelajaran yang sulit dan susah dimengerti. Faktor lain yang menyebabkan rendahnya hasil belajar ialah siswa kurang berinteraksi pada saat kegiatan pembelajaran, cepat melupakan materi yang diajarkan serta penggunaan media di kelas yang kurang optimal membuat siswa kurang aktif sehingga berimplikasi pada hasil belajar yang rendah.

Berdasarkan data dan informasi yang diperoleh dari guru mata pelajaran fisika bahwa kelas Xc merupakan kelas yang rata-rata masih di bawah standar ketuntasan minimum.

Untuk mengatasi permasalahan yang telah dipaparkan di atas maka model pembelajaran yang tepat untuk diterapkan adalah model learning cycle tipe 5E dengan media visual.

Model learning cycle merupakan model yang berpusat pada siswa, proses pembelajaran menjadi lebih bermakna karena mengutamakan pengalaman nyata, dan membentuk siswa menjadi aktif, kritis dan kreatif. [1]

Untuk tipe 5E sendiri terdiri dari engagement (pembangkitan minat) pada fase ini guru menciptakan situasi teka-teki yang sesuai dengan topik yang dipelajari oleh siswa, 
exploration (eksplorasi) siswa diberi kesempatan untuk bekerja sama dalam kelompok-kelompok kecil tanpa pengajaran langsung dari guru, explanation (penjelasan) pada tahap penjelasan ini guru di tuntut mendorong siswa untuk menjelaskan suatu konsep dengan kalimat/pemikiran sendiri, elaboration (elaborasi) pada fase ini ini siswa mengaplikasikan konsep yang mereka dapatkan ke dalam latihan soal, evaluation (evaluasi) Pada tahap akhir, evaluation, dilakukan evaluasi terhadap efektifitas fase-fase sebelumnya dan juga evaluasi terhadap pengetahuan.[2]

Media visual merupakan media yang memberikan gambaran menyeluruh dari yang konkrit sampai dengan abstrak. Media visual ini lebih bersifat realistis dan dapat dirasakan oleh sebagian besar panca indera kita khususnya indera penglihatan. Manfaat yang kita dapat dalam penggunaan media ini adalah pemakaiannya yang efektif dan efisien, praktis, dan lebih cepat dipahami oleh siswa.[3]

Hasil belajar tidak dapat dipisahkan dari apa yang terjadi dalam kegiatan di kelas, di sekolah maupun di luar sekolah. Untuk menggambarkan hasil belajar yang dicapai siswa, maka diadakan suatu proses penilaian seperti tes hasil belajar. Tes hasil belajar dilakukan untuk melihat sejauh mana tingkat keberhasilan siswa setelah melakukan proses belajar mengajar.

Menurut para ahli belajar mempunyai makna, kegiatan yang secara sadar dilakukan oleh seseorang untuk sebuah perubahan pengetahuan.[4] dan bahwa belajar adalah kegiatan berproses yang sangat pundamental dalam penyelenggaraan setiap jenis dan jenjang pendidikan. Berhasil atau gagalnya pencapaian tujuan pendidikan sangat bergantung pada proses yang dialami siswa baik ketika ia berada di sekolah maupun di lingkungan rumah atau keluarganya sendiri.[5]

Adapun rumusan masalah dalam penelitian ini adalah "Apakah dengan menerapkan model learning cycle tipe $5 \mathrm{E}$ dengan media visual dapat meningkatkan hasil belajar fisika pada siswa kelas XC SMA Negeri 2 Dolo?"

Sesuai dengan rumusan masalah di atas, maka tujuan penelitian ini adalah untuk meningkatkan hasil belajar fisika dengan menerapkan model learning cycle tipe 5E dengan media visual pada siswa kelas Xc SMA Negeri 2 Dolo.

Manfaat yang dapat diambil dari penelitian ini adalah bagi siswa dapat membangun kerja sama antara siswa, terbiasa dalam menyampaikan gagasannya serta membentuk siswa menjadi aktif, kritis dan kreatif, bagi guru dapat meningkatkan kreatifitas mengajar serta dapat dijadikan alternatif model pembelajaran yang dapat diterapkan di kelas sehingga hasil belajar lebih meningkat, bagi sekolah sebagai informasi, referensi, perbaikan pembelajaran dan peningkatan mutu pendidikan di sekolah khususnya di SMA Negeri 2 Dolo.

Dengan penerapan model learning cycle tipe $5 \mathrm{E}$ dengan media visual pembelajaran akan lebih optimal, efektif dan bermakna sehingga hasil belajar fisika siswa dapat dicapai dengan baik.

\section{METODOLOGI PENELITIAN}

Penelitian ini merupakan penelitian tindakan kelas (PTK) yang dilakukan dalam dua siklus. Masing-masing siklus melalui tahap perencanaan, tindakan, observasi, dan refleksi. Tahapan penelitian ini diadopsi dari alur PTK model Kurt Lewin yang dikembangkan oleh Kemmis dan Mc.Taggart. [6]

Subyek penelitian ini adalah seluruh siswa kelas Xc SMA Negeri 2 Dolo yang terdaftar pada tahun ajaran 2012/2013 yang berjumlah 21 orang siswa yang terdiri dari 9 orang siswa lakilaki dan 12 orang siswa perempuan, Data yang dikumpulkan dalam penelitian ini adalah hasil belajar siswa dalam mengerjakan soal-soal fisika yang diberikan melalui tes akhir setiap tindakan dan hasil observasi yang memuat cacatan mengenai kegiatan pembelajaran, baik yang berkaitan dengan guru (peneliti) maupun yang berkaitan dengan siswa, serta hasil belajar siswa.

Analisa data yang digunakan dalam penelitian ada dua yaitu teknik analisa data kuantitatif dan teknik analisa data kualitatif. [7]

Indikator kinerja dalam penelitian ini juga menggunakan indikator data Kuantitatif pada indikator ini masing-masing satuan pendidikan indikator yang menunjukkan keberhasilan pembelajaran atau peningkatan hasil belajar fisika siswa yang diterapkan di SMA Negeri 2 Dolo yaitu jika daya serap individu memperoleh nilai minimal $68 \%$ dari skor ideal dan ketuntasan klasikal minimal $80 \%$ dan indikator data kualitatif indikator ini dapat dilihat dari analisis observasi aktivitas siswa dan aktivitas guru. Penelitian ini dinyatakan berhasil jika aktivitas siswa dan guru serta penilaian afektifitas siswa dan kelompok telah berada dalam kategori baik atau sangat baik. 
Hipotesis tindakan pada penelitian ini adalah melalui penerapan model learning cycle tipe $5 \mathrm{E}$ dengan media visual dapat meningkatkan hasil belajar fisika pada siswa kelas Xc SMA Negeri 2 Dolo.

\section{HASIL DAN PEMBAHASAN}

Pada pembelajaran siklus I dilakukan dengan membagi siswa dalam 5 kelompok, setiap kelompok terdiri dari 4-5 orang, siswa dibagikan LKS untuk dikerjakan secara berkelompok, mendiskusikan dan mempresentasekan di depan kelas. Pelaksanaan pembelajaran ini ditunjang dengan skenario pembelajaran, RPP, lembar observasi guru dan siswa, lembar penilaian sikap siswa dan kelompok siswa, serta lembar evaluasi siswa.

Setelah dua kali pertemuan, selanjutnya dilakukan tes akhir untuk mengetahui hasil belajar siswa. Kekurangan dari pembelajaran pada siklus I adalah peneliti terlalu cepat dan terburu-buru dalam menyimpulkan materi sehingga kurang dipahami siswa, sebagian besar siswa tidak mencatat dan tidak memberikan tanggapan mengenai tujuan pembelajaran yang disampaikan dikarenakan siswa tidak dibiasakan, pada tiap kelompok kurang membangun kebersamaan disebabkan komunikasi yang kurang baik dan juga masih ada yang ragu dan takut untuk bertanya kepada guru ketika mendapat kesulitan, serta kurangnya perhatian siswa dalam proses pembelajaran sehingga pada saat mengerjakan soal membutuhkan waktu yang lebih lama untuk berpikir

Refleksi tindakan dilakukan guru guna mencari kekurangan dari pembelajaran siklus I, dan merekomendasikan kekurangan untuk diperbaiki pada siklus II. Pada hasil belajar siswa untuk siklus II diketahui bahwa hasil yang diperoleh sudah memenuhi indikator keberhasilan kuantitatif dengan ketuntasan klasikal sebesar $90,47 \%$ peningkatannya sebesar $11,31 \%$ dan daya serap klasikal sebesar $81,19 \%$ peningkatannya sebesar $10,00 \%$. Hasil yang diperoleh pada siklus II dapat meningkat lebih baik dari siklus I karena faktor-faktor penyebab kegagalan pada siklus I dapat diminimalisir.

Pada hasil belajar siswa pada siklus I dan siklus II ditunjukkan secara lengkap pada Tabel 1.
Tabel 1. Hasil Belajar Siswa Siklus I dan Siklus II

\begin{tabular}{|c|l|c|c|}
\hline \multirow{2}{*}{ No. } & \multirow{2}{*}{ Aspek Perolehan } & \multicolumn{2}{|c|}{ Hasil } \\
\cline { 3 - 4 } 1. & Skor maksimal & 100 & 100 \\
\hline 2. & Skor tertinggi & 90 & 90 \\
\hline 3. & $\begin{array}{l}\text { Banyak siswa yang } \\
\text { memperoleh skor } \\
\text { tertinggi }\end{array}$ & 1 orang & 2 orang \\
\hline 4. & Skor terendah & 40 & 60 \\
\hline 5. & $\begin{array}{l}\text { Banyak siswa yang } \\
\text { memperoleh skor } \\
\text { terendah }\end{array}$ & 2 orang & 1 orang \\
\hline 6. & Skor Rata-rata siswa & $70,95 \%$ & $80,23 \%$ \\
\hline 7. & $\begin{array}{l}\text { Banyaknya siswa yang } \\
\text { tuntas }\end{array}$ & 16 orang & 19 orang \\
\hline 8. & $\begin{array}{l}\text { Banyaknya siswa yang } \\
\text { tidak tuntas }\end{array}$ & 5 orang & 2 orang \\
\hline 9. & $\begin{array}{l}\text { Persentase daya serap } \\
\text { klasikal }\end{array}$ & $71,19 \%$ & $81,19 \%$ \\
\hline 10. & $\begin{array}{l}\text { Persentase ketuntasan } \\
\text { belajar klasikal }\end{array}$ & $76,19 \%$ & $90,47 \%$ \\
\hline
\end{tabular}

Berdasarkan analisa tes hasil yang dilakukan pada siklus I, diketahui bahwa hasil belajar fisika siswa kelas Xc SMA Negeri 2 Dolo sudah cukup baik, hanya ada 5 siswa dari 21 siswa yang tidak memenuhi standar ketuntasan individu (68\%) sedangkan ketuntasan belajar klasikal (KBK) siswa mencapai 76,19\% dan daya serap klasikal (DSK) siswa mencapai $71,19 \%$, hasil yang diperoleh ini belum memenuhi standar ketuntasan belajar klasikal dan daya serap klasikal yang harus mencapai $80 \%$.

Untuk Peningkatan aktifitas guru dan siswa dijelaskan sebagai berikut: pada aktifitas guru pada pembelajaran siklus I, pertemuan I sebesar $85,00 \%$ dan pertemuan II sebesar $87,50 \%$ berada pada kategori baik. Untuk pembelajaran siklus II, pertemuan I sebesar $90,00 \%$ dan pertemuan II sebesar 97,50 masing-masing berada pada kategori sangat baik.

Pada aktifitas siswa pembelajaran siklus I, pertemuan I sebesar $72,50 \%$ berada pada kategori cukup dan pertemuan II sebesar $82,50 \%$ berada pada kategori baik. Untuk pembelajaran siklus II, pertemuan I sebesar $92,50 \%$ dan pertemuan II sebesar $92,70 \%$ masing-masing berada pada kategori sangat baik.

Berdasarkan hasil observasi guru dan siswa selama kegiatan pembelajaran tiap siklus, diperoleh persentase aktifitas guru pada siklus I sebesar $86,25 \%$ dan siklus II sebesar $96,25 \%$ disini terjadi peningkatan aktifitas guru sebesar $10,00 \%$.

Sedangkan untuk observasi siswa selama kegiatan pembelajaran tiap siklus, diperoleh persentase aktifitas siswa pada siklus I sebesar 
$77,50 \%$ dan pada siklus II sebesar 95,00\% disini terjadi peningkatan aktifitas siswa sebesar $17,50 \%$.

Untuk melihat peningkatan aktivitas guru dan aktivitas siswa dapat dilihat pada Gambar 1 dan Gambar 2.

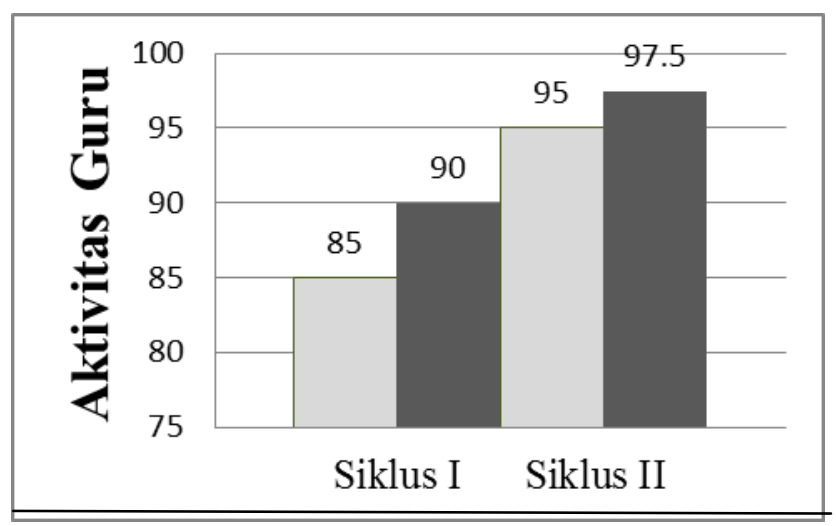

Gambar 1. Grafik Peningkatan Aktivitas Guru

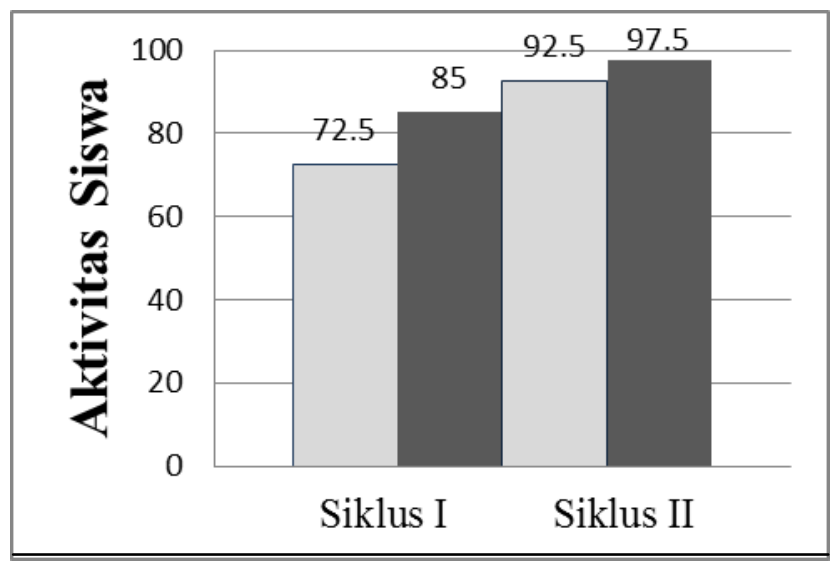

Gambar 2. Grafik Peningkatan Aktivitas Siswa

Penekanan guru pada setiap tahap pembelajaran berpengaruh terhadap aktivitas siswa. Guru berusaha mendorong siswa mengungkapkan ide-ide mereka dan membangun konsepnya melalui pembelajaran serta mendorong siswa agar lebih aktif dalam melakukan kegiatan pembelajaran karena dari pelaksanaan kegiatan ini mereka diharapkan lebih aktif dalam mencari dan memahami materi yang diajarkan. Dari Gambar 1 dan 2 tersebut terlihat terjadi peningkatan aktifitas guru dan siswa dari siklus I ke siklus II, sehingga dapat dikatakan bahwa penerapan model learning cycle tipe $5 \mathrm{E}$ dengan media visual dapat meningkatkan aktifitas guru dan siswa.

Peningkatan Hasil Belajar Siswa dijelaskan sebagai berikut: berhasilnya penelitian ini ditunjukkan pada peningkatan hasil belajar siswa dari siklus I ke siklus II, terlihat dari ketuntasan klasikal yang diperoleh pada siklus I yaitu $79,16 \%$ dimana masih terdapat 5 orang siswa yang belum tuntas sedangkan ketuntasan klasikal pada siklus II yaitu 90,47\% dimana terdapat 2 orang siswa yang belum tuntas, yang berarti terjadi peningkatan ketuntasan klasikal sebesar $11,31 \%$. Selain itu, diketahui pula bahwa peningkatan daya serap klasikal dari siklus I ke siklus II, dimana daya serap klasikal pada siklus I sebesar $71,19 \%$ dan daya serap klasikal pada siklus II sebesar $81,19 \%$. Hal tersebut berarti terjadi peningkatan daya serap klasikal sebesar 10,00\%.

Untuk melihat lebih jelas grafik peningkatan yang terjadi dapat dilihat pada Gambar 3 dan Gambar 4.

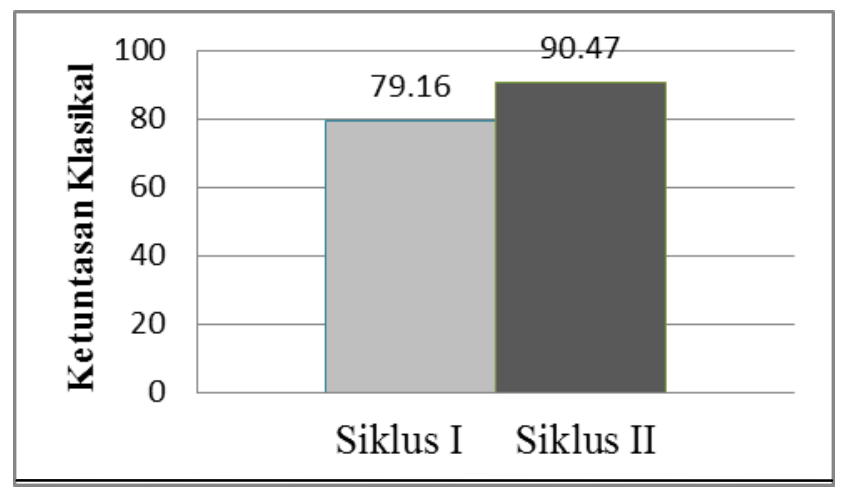

Gambar 3. Grafik Peningkatan Ketuntasan Klasikal

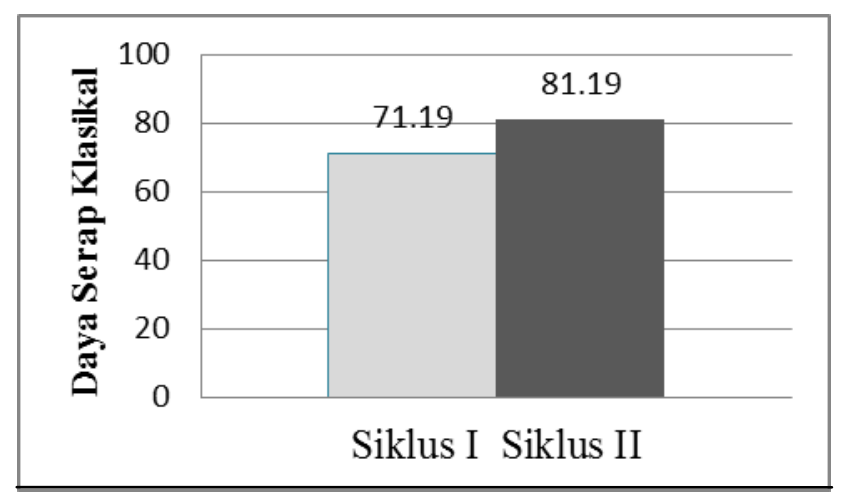

Gambar 4. Grafik Peningkatan Daya Serap Klasikal

Berdasarkan uraian di atas, dapat dikatakan bahwa model learning cycle tipe 5E dengan media visual meningkatkan hasil belajar fisika pada siswa kelas Xc SMA Negeri 2 Dolo.

\section{KESIMPULAN DAN SARAN}

Berdasarkan hasil analisa data dan pembahasan pada penelitian ini, maka dapat disimpulkan bahwa penerapan model learning 
cycle tipe 5E dengan media visual dapat meningkatkan hasil belajar fisika pada siswa kelas Xc SMA Negeri 2 Dolo.

Hasil observasi aktivitas siswa dan guru pada siklus I berada pada kategori baik dan cukup, sedangkan pada siklus II berada pada kategori sangat baik.

Hal ini dapat dilihat pada peningkatan hasil belajar siswa dari siklus I ke siklus II. Untuk hasil belajar siklus I diperoleh nilai ketuntasan belajar klasikal sebesar $79,16 \%$ dan daya serap klasikal $71,19 \%$. Sedangkan pada siklus II diperoleh nilai ketuntasan belajar klasikal sebesar $90,47 \%$ dan daya serap klasikal $81,19 \%$ yang artinya sudah melewati standar ketuntasan klasikal siswa, peningkatan DSK dan KBK dari siklus I ke siklus II sebesar $10,00 \%$ dan $11,31 \%$. Untuk

Saran peneliti kepada guru maupun calon guru yang ingin menerapkan model learning cycle tipe 5E dengan media visual disarankan memperhatikan beberapa hal yaitu: model learning cycle tipe $5 \mathrm{E}$ dengan media visual harus semenarik mungkin dan punya daya tarik yang besar sehingga membuat siswa lebih aktif dalam KBM, harus lebih memperhatikan dan mengefektifkan waktu selama pembelajaran dan menciptakan suasana keakraban antara guru dengan siswa, tidak membuat jarak antara keduanya, menumbuhkan rasa percaya diri siswa, memberikan perhatian dan motivasi untuk senantiasa menjaga kerja sama dalam kelompok

\section{UCAPAN TERIMA KASIH}

Pada kesempatan ini, peneliti juga mengucapkan terima kasih kepada bapak Dr. Darsikin, M.Si selaku pembahas I dan Drs. H. Muhammad Ali, M.Si selaku pembahas II atas segala saran arahan yang telah diberikan. Dan juga kepada ibu Nurjannah, S.Pd, M.Pd selaku reviewer manuskip atas masukan dan arahan selama proses reviuw (penalaahan).

\section{DAFTAR PUSTAKA}

[1] Fajaroh, F. dan Dasna, I. W. 2003 Penggunaan Model Learning Cycle Untuk Meningkatkan Motivasi Belajar Dan Hasil Belajar Kimia Zat Aditif Dalam Bahan Makanan Pada Siswa Kelas Ii SMU Negeri 1 TumpangMalang. Jurnal Pendidikan dan Pembelajaran vol II (2) Oktober 2004, hal 112-122.

[2] Wena, M. 2009. Strategi Pembelajaran Inovatif. Jakarta: PT Bumi Aksara.

[3] Chandra,. 2011. Makalah Media Visual, [Online]. Tersedia:
Ceva24Chandra.blogspot.com/2011/06/makalahmedia-visual.html. [13 Agustus 2012].

[4] Depdiknas. 2003. Penelitian Tindakan Kelas. Jakarta: Departemen Pendidikan Nasional.

[5] Slameto. 2003. Belajar Dan Faktor-Faktor yang Mempengaruhi. Jakarta: Rineka Cipta.

[6] Syah, Muhibbin. 2003. Psikologi Belajar. Jakarta: PT Raja Grafindo Persada.

[7] Tim Penyusun. 2005. Pedoman Penyusunan dan penilaian Karya Ilmiah. Palu: FKIP UNTAD. 